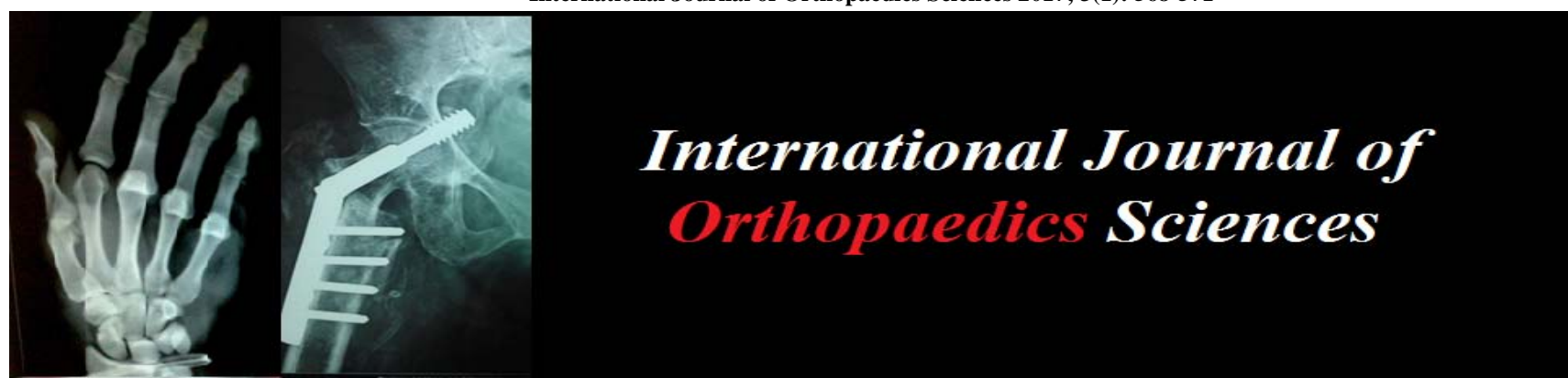

ISSN: 2395-1958

IJOS 2017; 3(1): 568-571

(C) 2017 IJOS

www.orthopaper.com

Received: 22-11-2016

Accepted: 23-12-2016

Subodh Kumar Pathak

Department of Orthopedics,

Pramukhswami Medical College,

Karamsad, Gujarat, India

Pritam Maheshwari

Department of Orthopedics,

Pramukhswami Medical College,

Karamsad, Gujarat, India

Prahlad Ughareja

Department of Orthopedics,

Pramukhswami Medical College,

Karamsad, Gujarat, India

Shaurya Shah

Department of Orthopedics,

Pramukhswami Medical College,

Karamsad, Gujarat, India

Prashanth Raj M

Department of Orthopedics,

Manipal Hospitals, Bangalore, India

Sandeep Kumar Gour

Department of Orthopedics, Sparsh Hospitals, Bangalore India
Correspondence

Subodh Kumar Pathak

Department of Orthopedics,

Pramukhswami medical college,

Karamsad, Gujarat, India

\section{Is vitamin D deficiency a modern epidemic in tropical countries?}

\author{
Subodh Kumar Pathak, Pritam Maheshwari, Prahlad Ughareja, Shaurya \\ Shah, Prashanth Raj M and Sandeep Kumar Gour
}

DOI: http://dx.doi.org/10.22271/ortho.2017.v3.i1i.82

\section{Abstract}

Background: Vitamin D deficiency is a global health problem. Prolong deficiency of Vitamin D leads to alteration in calcium metabolism thereby leading to rickets in children and osteomalacia in adults. Deficiency of vitamin D is also an important cause of nonspecific back pain and other metabolic disturbances. The prevalence of hypovitaminosis is high in western countries and in this study we aim to find out the prevalence in general population.

Methodology: Patients presenting to orthopaedics out patient with low back pain, generalised body pain for more than 3 months were included in the study. Total of 139 patients were included in the study. Mean age of the patients was 53.68 years. Details such as age, sex, diet, physical activity, body mass index and smoking status were also noted.

Results: The mean vitamin D level of the overall study population was $37.8 \mathrm{ng} / \mathrm{ml}$ ranging from 12 $\mathrm{ng} / \mathrm{ml}$ to $49.2 \mathrm{ng} / \mathrm{ml}$. The mean vitamin D levels for males was $38.6 \mathrm{ng} / \mathrm{ml}$ ranging from $21 \mathrm{ng} / \mathrm{ml}$ to $49.2 \mathrm{ng} / \mathrm{ml}$. The mean vitamin D level for females was $26.2 \mathrm{ng} / \mathrm{ml}$ ranging from $12 \mathrm{ng} / \mathrm{ml}$ to $47.8 \mathrm{ng} / \mathrm{ml}$. $79.33 \%$ of the study population had low vitamin D. Significant difference between males and females was seen. The deficiency of vitamin $\mathrm{D}$ was more severe and more common in the older age group.

Conclusion: The prevalence of vitamin D deficiency is more common than it seems. There is a need for better education of general population regarding this ongoing epidemic and ways to tackle the deficiency of this sunshine vitamin.

Keywords: Vitamin D, prevalence, musculoskeletal pain, smokers, chronic low back pain

\section{Introduction}

Vitamin D deficiency is a health problem that affects around one billion people globally ${ }^{[1]}$. Vitamin D deficiency is widespread in individuals irrespective of their age, gender, race and geography. This vitamin plays a physiological role in body and also as local autocrine hormone in bones and muscles ${ }^{[2]}$. The role of vitamin $\mathrm{D}$ in bone metabolism is through the increased intestinal and renal absorption of calcium and also regulated the overall bone calcium in presence of parathyroid hormone. Prolonged deficiency of vitamin D alters the whole calcium metabolism leading to rickets and osteomalacia ${ }^{[3]}$. Even in tropical country like India with adequate day light and sunshine there is high prevalence of vitamin D deficiency in the population ${ }^{[4]}$. With the discovery of vitamin D receptors in muscle cells the theory of nonspecific muscle pain in vitamin D deficiency could be explained ${ }^{[5]}$, this could lead to frequent falls and increased risk of fracture due to frequency of fall and poor bone quality. With the skeletal effects of vitamin d deficiency there are also extra skeletal effects on cardiovascular system, endocrine system, immunity and increased risk of developing colorectal, prostate, breast, pancreatic, and esophageal cancer ${ }^{[6-8]}$. In tropical country like India the deficiency is multifactorial which has led to the occurrence of this epidemic. This deficiency has a burden on the health care system of India. Limitation of the sun exposure due to life style patterns and cultural taboos is also an important cause. The diet pattern in socioeconomically challenged population makes them more vulnerable to deficiency of all vitamins including vitamin $D$ [9]. The aim of this study was to find out the prevalence of hypovitaminosis $\mathrm{D}$ in general population and understand the gravity of the problem and take necessary steps in early diagnosis and treatment of deficiency of Vitamin D. 


\section{Materials and Methods}

This is an observational study was conducted at Tertiary care hospital. This study was examined and approved by Hospital ethical committee. Patients presenting to general orthopaedics outpatient department with generalised body pain for more than 3 months, chronic low back pain, non-specific musculoskeletal pain, bony pain, within the age of 18 years to 65 years were enrolled in this study. The mean age of the study population was 53.68 years ranging from 18 years to 65 years. Exclusion criteria for the study was patients with malignancies, parathyroid disorders, patients on treatment of vitamin $\mathrm{D}$ taken in past 2 month, patients on treatment for osteoporosis or metabolic bone disorder. Demographic details such as age, sex, diet, and selected health risk factors like physical activity, body mass index (Table 2) and smoking status were also noted. Age and sex distribution of the population was done.(Figure 1).In our study 92 patients were above the age of 50 years.(66.18\% of study population).The level of vitamin D was noted. Vitamin D levels were classified according to vitamin D council values as stated in Table 1.

2.1 Statistical Analysis: STATA 14.0 was used for data variation analysis. Where suitable, 95\% confidence intervals (CI) were calculated as a measure of precision. Statistical association between smoking and Vitamin D levels was done. Vitamin D levels in men and women were analysed using the student's $\mathrm{t}$ test. The $\mathrm{p}$ value for statistical significance was set at $p<0.05$

Table 1: Vitamin D values as per Vitamin D council

\begin{tabular}{|c|c|}
\hline Vitamin D status & Blood level \\
\hline Deficient & $0-30 \mathrm{ng} / \mathrm{ml}$ \\
\hline Insufficient & $31-39 \mathrm{ng} / \mathrm{ml}$ \\
\hline Sufficient & $40-80 \mathrm{ng} / \mathrm{ml}$ \\
\hline Toxic & $>150 \mathrm{ng} / \mathrm{ml}$ \\
\hline
\end{tabular}

Table 2: Demographic data

\begin{tabular}{|c|c|c|c|}
\hline & Male $(\mathbf{n}=\mathbf{5 3})$ & Female (n=86) & Total (n=139) \\
\hline Mean Age & $\mathbf{5 2 . 2 y e a r s}$ & $\mathbf{5 6 . 6 y e a r s}$ & $\mathbf{5 3 . 6 8 y e a r s}$ \\
\hline Physical Activity Level & & & $11.51 \%(\mathrm{n}-=16)$ \\
\hline Sedentary & $7.54 \%(\mathrm{n}=4)$ & $13.95 \%(\mathrm{n}=12)$ & $17.27 \%(\mathrm{n}=24)$ \\
\hline Low & $13.20 \%(\mathrm{n}=7)$ & $19.76 \%(\mathrm{n}=17)$ & $51.80 \%(\mathrm{n}=72)$ \\
\hline Moderate & $43.39 \%(\mathrm{n}=23)$ & $56.97 \%(\mathrm{n}=49)$ & $19.42 \%(\mathrm{n}=27)$ \\
\hline High & $35.84 \%(\mathrm{n}=19)$ & $9.31 \%(\mathrm{n}=8)$ & $6.47 \%(\mathrm{n}=9)$ \\
\hline BMI \% Low & $3.78 \%(\mathrm{n}=2)$ & $8.16 \%(\mathrm{n}=7)$ & $40.28 \%(\mathrm{n}=56)$ \\
\hline Normal & $39.62 \%(\mathrm{n}=21)$ & $40.69 \%(\mathrm{n}=35)$ & $(\mathrm{n}=42)$ \\
\hline Overweight & $43.39 \%(\mathrm{n}=23)$ & $22.09 \%(\mathrm{n}=19)$ & $(\mathrm{n}=32)$ \\
\hline Obese & $13.20 \%(\mathrm{n}=7)$ & $29.06 \%(\mathrm{n}=25)$ & \\
\hline
\end{tabular}

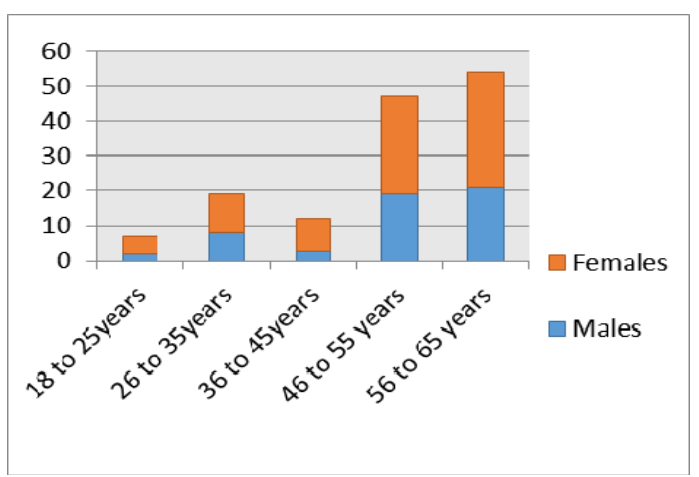

Fig 1: Age and Sex

\section{Results}

The mean vitamin D level of the overall study population was $37.8 \mathrm{ng} / \mathrm{ml}$ ranging from $12 \mathrm{ng} / \mathrm{ml}$ to $49.2 \mathrm{ng} / \mathrm{ml}$. The mean vitamin $\mathrm{D}$ levels for males was $38.6 \mathrm{ng} / \mathrm{ml}$ ranging from 21 $\mathrm{ng} / \mathrm{ml}$ to $49.2 \mathrm{ng} / \mathrm{ml}$. The mean vitamin $\mathrm{D}$ level for females was 26.2 ranging from $12 \mathrm{ng} / \mathrm{ml}$ to $47.8 \mathrm{ng} / \mathrm{ml}$. There was a statistically significant difference in vitamin $\mathrm{D}$ levels between males and females ( $p$ vale $<0.05$ ) (Table no 4). The level of vitamin $\mathrm{D}$ and its interpretation as deficient or toxic for the study population is given in Table no 3. Hypovitaminosis D was seen more commonly in Overweight and obese population as compared to population with normal BMI. The mean vitamin $\mathrm{D}$ level in Obese and overweight population was $34.6 \mathrm{ng} / \mathrm{ml}$ and that of population of normal BMI was $47.2 \mathrm{ng} / \mathrm{ml}$. The mean Vitamin D level in smokers was $32.2 \mathrm{ng} / \mathrm{ml}$ and that in non-smokers was $41.8 \mathrm{ng} / \mathrm{ml}$. (Figure 2). There was a statistically significant difference between the vitamin $\mathrm{D}$ level among smokers and non-smokers ( $\mathrm{p}$ value
$=0.02$ ). The overall prevalence of hypovitaminosis $\mathrm{D}$ in the population was $79 \%(n=110)$. (Figure 4$)$. The deficiency of Vitamin D was seen more in the older age group (Figure3). Mean vitamin D level in high physical activity level was 41.28 $\mathrm{ng} / \mathrm{ml}$ while that in sedentary activity was $16.12 \mathrm{ng} / \mathrm{ml}$. None of the patients in the study had toxic levels of vitamin D.

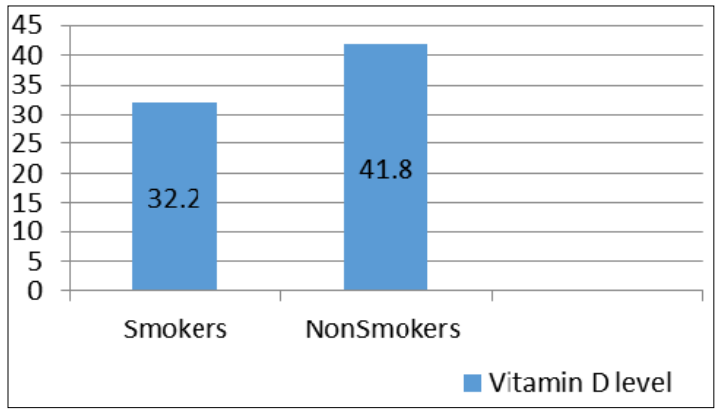

Fig 2: Mean Vitamin D level in smokers and non-smokers

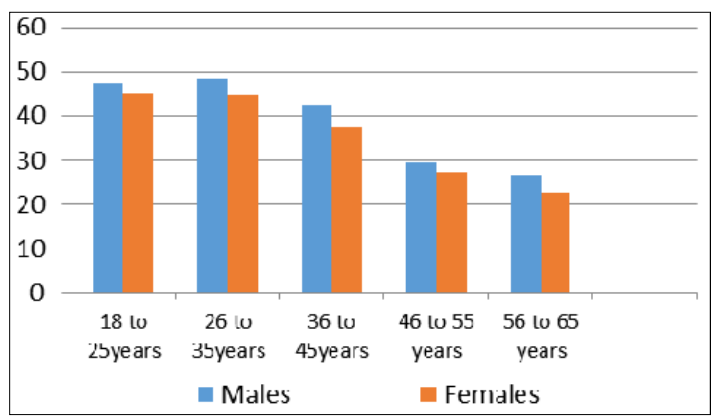

Fig 3: Mean value of Vitamin D according to age group. 
Table 3: Vitamin D levels in males and females

\begin{tabular}{|c|c|c|c|}
\hline Vitamin D level & Interpretation & Males(n=53) & Females(n=86) \\
\hline $0-30 \mathrm{ng} / \mathrm{ml}$ & Deficient & $23(43.39 \%)$ & $49(56.97 \%)$ \\
\hline $31-39 \mathrm{ng} / \mathrm{ml}$ & Insufficient & $17(32.07 \%)$ & $21(24.43 \%)$ \\
\hline $40-80 \mathrm{ng} / \mathrm{ml}$ & Sufficient & $13(24.54 \%)$ & $16(18.60 \%)$ \\
\hline$>150 \mathrm{ng} / \mathrm{ml}$ & Toxic & $0(0 \%)$ & $0(0 \%)$ \\
\hline
\end{tabular}

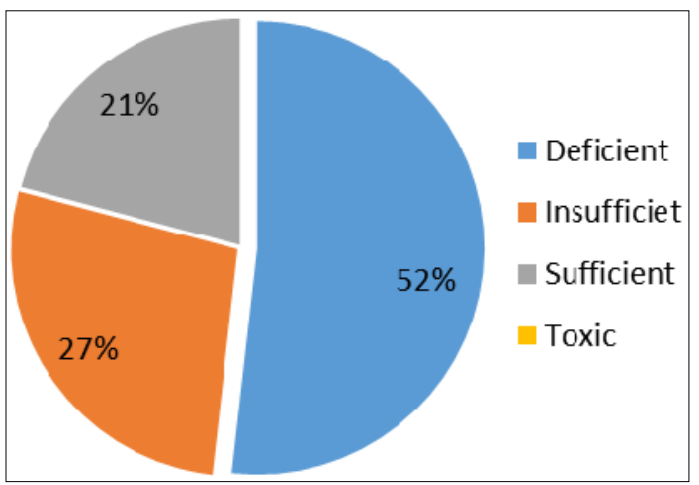

Fig 4: Vitamin D status in study population

Table 4: Two-sample $t$ test of Vitamin D levels (males and females)

\begin{tabular}{|c|c|c|c|}
\hline \multicolumn{4}{|c|}{ Vitamin D level } \\
\hline & Mean \pm SD & Std error & 95\% Conf interval \\
\hline Males $(\mathrm{n}=53)$ & $38.6 \pm 5.5$ & 0.7554 & $37.08401-40.11599$ \\
\hline Females $(\mathrm{n}=86)$ & $26.2 \pm 6.1$ & 0.6577 & $24.89216-27.50784$ \\
\hline $\mathrm{P}$ value $=0.01 *$, Statistically significant \\
\hline
\end{tabular}

\section{Discussion}

In studies conducted in several continents, vitamin D deficiency is the most common condition affecting more than $50 \%$ population living in Unites states, Canada, Mexico, Asia, Europe, New Zealand, and Australia ${ }^{[10]}$. This study was conducted to find out the prevalence of low serum $25(\mathrm{OH}) \mathrm{D}$ in population visiting the general orthopedic outpatient with nonspecific musculoskeletal pain and low back pain. In our study $41.6 \%$ of the patients with nonspecific musculoskeletal pain had deficiency of vitamin $\mathrm{D}$ with values being less than $30 \mathrm{ng} / \mathrm{ml}$. The occurrence of musculoskeletal pain in vitamin D deficiency has drawn attention of many investigators and many studies have shown association between it. In 2003 Plotnikoff et al studied 150 patients with musculoskeletal pain and showed that $93 \%$ of them were deficient in Vitamin D ${ }^{[11]}$. In a recent study by Sadat-Ali M et al ${ }^{[12]}$ in young healthy man in Saudi Arabia revealed the prevalence of hypovitaminosis D to be 28 to $37 \%$. In other study conducted in Saudi Arabia in population at high risk the prevalence of Vitamin D deficiency was found to be $50 \%$ to $80 \%{ }^{[13]}$. Recent population survey in the U.S. showed that the prevalence of vitamin D insufficiency has doubled in the last 10 years, currently affecting not less than $90 \%$ of pigmented populations (blacks, Hispanics and Asians and around $3 / 4$ of the Caucasian population ${ }^{[14,15]}$. In our study Vitamin D deficiency was seen in $52 \%$ of patients, while insufficiency was seen in $27.33 \%$ of patients. Overall low vitamin D was seen in $79.33 \%$ of the population. Low vitamin D levels were seen in $75.47 \%$ of males and $81.39 \%$ of females. Smoking is an independent risk factor which has detrimental effect on metabolism of calcium and vitamin D. The depression vitamin D PTH axis is seen in chronic smokers which eventually affects the bone metabolism and contributes to the increased risk of osteoporosis and fractures ${ }^{[16]}$. In this study the mean vitamin D level in smokers was $32.2 \mathrm{ng} / \mathrm{ml}$ which was lower than non-smokers (41.8ng/ml) (Figure 2). In this study hypovitaminosis was seen in $86.2 \%$ of elderly patients. (Figure 3). Exposure to sunlight helps the human body to synthesize the required vitamin D. However due to cultural practice exposure to sun is reduced. High concentration of melanin in the skin slows down the process of vitamin D production as it acts as a natural sun screen and the production of vitamin D goes down with ageing ${ }^{[17]}$. People working indoor, wearing extensive clothing, use of sun screen, obese, aged, smokers are at higher risk of deficiency. In country like India where the sun shines throughout the year which allows the synthesis of vitamin $\mathrm{D}$ but certain regions of the country have shown high prevalence of vitamin $d$ deficiency. High index of suspicion for deficiency of vitamin $\mathrm{D}$ should be kept in mind treating patients presenting with vague generalised body pain and serum $25(\mathrm{OH}) \mathrm{D}$ should be the part of the metabolic investigation sent for these patients. There is a need for better education of general population regarding this ongoing epidemic and ways to tackle the deficiency of this sunshine vitamin.

\section{Acknowledgements}

No funding contribution was received towards selection, extraction, or analysis of the data from any source, nor was any funding received for compilation of this article.

\section{References}

1. Hollick MF, Chen TC. Vitamin D deficiency a worldwide problem with health consequences. Am J Clin Nutr. 2008; 87:10805-68.

2. Hollis BW, Wagner CL. Clinical review: the role of the parent compound vitamin $\mathrm{D}$ with respect to metabolism and function: Why clinical dose intervals can affect clinical outcomes. J Clin Endocrin Metab. 2013; 98(12):4619-4628

3. Pike JW, Zella LA, Meyer MB, Fretz JA, Kim S. Molecular actions of 1,25-dihydroxyvitamin D3 on genes involved in calcium homeostasis. J Bone Miner Res. 2007; 22(2):V16-9.

4. Alagöl F, Shihadeh Y, Boztepe H, Tanakol R, Yarman S, Azizlerli $\mathrm{H}$ et al. Sunlight exposure and vitamin D deficiency in Turkish women. J Endocrinol Invest. 2000; 23(3):173-7.

5. Simpson RU, Thomas GA, Arnold AJ. Identification of 1, 25-dihydroxyvitamin D3 receptors and activities in muscle. J Biol Chem. 1985; 260(15):8882-8891.

6. Gorham ED, Garland CF, Garland FC, Grant WB, Mohr $\mathrm{SB}$, Lipkin $\mathrm{M}$ et al. Optimal vitamin D status for colorectal cancer prevention: A quantitative metaanalysis. Am. J. Prev. Med. 2007; 32:210-216. doi:10.1016/j.amepre.2006.11.004.

7. Ahonen MH, Tenkanen L, Teppo L, Hakama M, Tuohimaa P. Prostate cancer risk and prediagnostic serum 25-hydroxyvitamin D levels (Finland) Cancer Causes Control. 2000; 11:847-852. Doi: 10.1023/A: 1008923802001 .

8. Garland CF, Gorham ED, Mohr SB, Grant WB, Giovannucci EL, Lipkin $\mathrm{M}$ et al. Vitamin $\mathrm{D}$ and prevention of breast cancer: Pooled analysis. J. Steroid Biochem. Mol. Biol. 2007; 103:708-711. doi: 10.1016/j.jsbmb.2006.12.007

9. GR, Gupta A. Vitamin D Deficiency in India: Prevalence, Causalities and Interventions. Nutrients, 2014; 6(2):729775. http://doi.org/10.3390/nu6020729.

10. Dini C, Bianchi A. The potential role of vitamin D for prevention and treatment of tuberculosis and infectious diseases. Ann Ist Super Sanit. 2012; 48(3):319-27. 
11. Plotnikoff GA, Quigley JM. Prevalence of severe hypovitaminosis D in patients with persistent, nonspecific musculoskeletal pain. Mayo Clin Proc. 2003; 78(12):1463-70.

12. Sadat-Ali M, AlElq A, Al-Turki H, Al-Mulhim F, Al-Ali A. Vitamin D levels in healthy men in eastern Saudi Arabia. Ann Saudi Med. 2009; 29:378-8.

13. Mohammed S, Addae S, Suleiman S, Adzaku F, Annobil $\mathrm{S}$, Kaddoumi $\mathrm{O}$ et al. Serum calcium, parathyroid hormone, and vitamin D status in children and young adults with sickle cell disease. Ann Clin Biochem. 1993; 30:45-51.

14. Mandarino, Natália Ribeiro et al. Is Vitamin D Deficiency a New Risk Factor for Cardiovascular Disease? The Open Cardiovascular Medicine Journal 9. 2015; 9:40-49. PMC. Web. 8 Oct. 2016.

15. Adams JS, Hewison M. Update in vitamin, D. J Clin Endocrinol Metab. 2010; 95:471-8

16. Brot C, Jorgensen NR, Sorensen $\mathrm{OH}$. The influence of smoking on Vitamin D status and calcium metabolism, Eur J Clin Nutr. 1999; 53(12):920-6

17. Naeem Z. Vitamin D Deficiency- An Ignored Epidemic. International Journal of Health Sciences. 2010; 4(1):V-VI. 